\title{
Chapter 2 \\ Future Climate Projections in Africa: Where Are We Headed?
}

\author{
Evan Girvetz, Julian Ramirez-Villegas, Lieven Claessens, Christine Lamanna, \\ Carlos Navarro-Racines, Andreea Nowak, Phil Thornton, \\ and Todd S. Rosenstock
}

\subsection{Introduction}

Farmers in Africa-like those across the globe-face rising temperatures and more extreme weather associated with climate change (Snyder 2016; IPCC 2012). Much of Africa's vulnerability to climate change lies in the fact that its agricultural systems remain largely rain-fed, with few technological inputs. The majority of Africa's farmers

\footnotetext{
E. Girvetz $(\bowtie)$

International Center for Tropical Agriculture (CIAT), Nairobi, Kenya

e-mail: E.Girvetz@cgiar.org

\section{J. Ramirez-Villegas · C. Navarro-Racines}

International Center for Tropical Agriculture (CIAT), Cali-Palmira, Colombia

CGIAR Research Program on Climate Change, Agriculture and Food Security (CCAFS),

Copenhagen, Denmark

e-mail: J.R.villegas@cgiar.org; C.E.navarro@cgiar.org

\section{Claessens}

CGIAR Research Program on Climate Change, Agriculture and Food Security (CCAFS),

Copenhagen, Denmark

International Institute of Tropical Agriculture (IITA), Arusha, Tanzania

e-mail: 1.claessens@cgiar.org

C. Lamanna · A. Nowak

World Agroforestry Centre (ICRAF), Nairobi, Kenya

e-mail: C.Lamanna@cgiar.org; A.Nowak@cgiar.org

P. Thornton

International Livestock Research Institute (ILRI), Nairobi, Kenya

e-mail: p.thornotn@cgiar.org

\section{T. S. Rosenstock}

World Agroforestry Centre (ICRAF), Kinshasa, Democratic Republic of the Congo

e-mail: T.Rosenstock@cgiar.org
} 
work on a small-scale or subsistence level, with their opportunities limited by persistent poverty, lack of access to infrastructure and information, and challenges related to policy and governance. Climate change is expected to have major negative impacts on the livelihoods and food security of such farmers. Governments and development professionals must confront the challenge of helping them to adapt (Shackleton et al. 2015).

This paper offers a general overview of historical climate change in Africa, and in particular how it has already led to rising temperatures and increased rainfall variability. It then examines the models that provide projections-with varying levels of certainty - of what climate change will mean for farmers across eastern and southern Africa in the coming decades (ESA).

The paper also highlights the strengths and limitations of the available information regarding the effects of climate change. Adapting to climate change requires better projections of the specific climate hazards that will be faced at the national, regional and local levels (Challinor et al. 2007; Muller et al. 2011). In particular, implementation of climatesmart agriculture (CSA) projects has been constrained by the lack of information on the best responses in specific regions. There are serious gaps in observed historical weather data at the local level across the continent, and the continuing collection of such data still lags far behind where it should be. Strengthening the database of observed weather is critical to understanding the changes that have occurred already, to project future changes and their impacts, and to plan appropriately to address them. Once collected and analyzed, climate data must be communicated in ways that help development practitioners and decision-makers understand climate impacts in specific places. Good tools are available, but practitioners at the local level must have the access and training to use them.

Much work remains to be done. However, given that the impacts of climate change are already being felt on the ground, it is imperative that adaptation begins immediately. Even in places where projections are uncertain, steps can be taken right now to implement CSA practices and make farmers more resilient in the face of climate change.

\subsection{Past and Present: Evidence Africa's Climate Has Already Changed}

There is clear evidence that average temperatures have become warmer across the globe. In Africa these changes became apparent starting in about 1975, and since then temperatures have increased at a rate of about $0.03{ }^{\circ} \mathrm{C}$ per year (NOAA 2018; Hartmann et al. 2013). In those regions of Africa for which data are available, most have also recorded an increase in the incidence of extreme temperatures as well as longer heat waves (Seneviratne et al. 2012).

Historic variability can provide useful context for understanding climate change. Climate variability can be thought of as a bell curve, with weather in any given year most likely to cluster around the average (the top of the bell) and extremes of temperature or precipitation occurring less often (the flatter parts of the curve). Climate change can shift both the mean and the overall shape of the bell curve, often flattening it out because of the rising frequency of extremes (Kirtman et al. 2013). 
Records are constantly being broken: in Africa 19 of the past 20 years have been hotter than any previous year on record. The new normal for temperature is hotter than ever experienced in the recorded past.

Historic precipitation patterns show that much of Africa is drying (Hartmann et al. 2013, Fig. 2.1). West Africa and parts of southern Africa, particularly Zambia

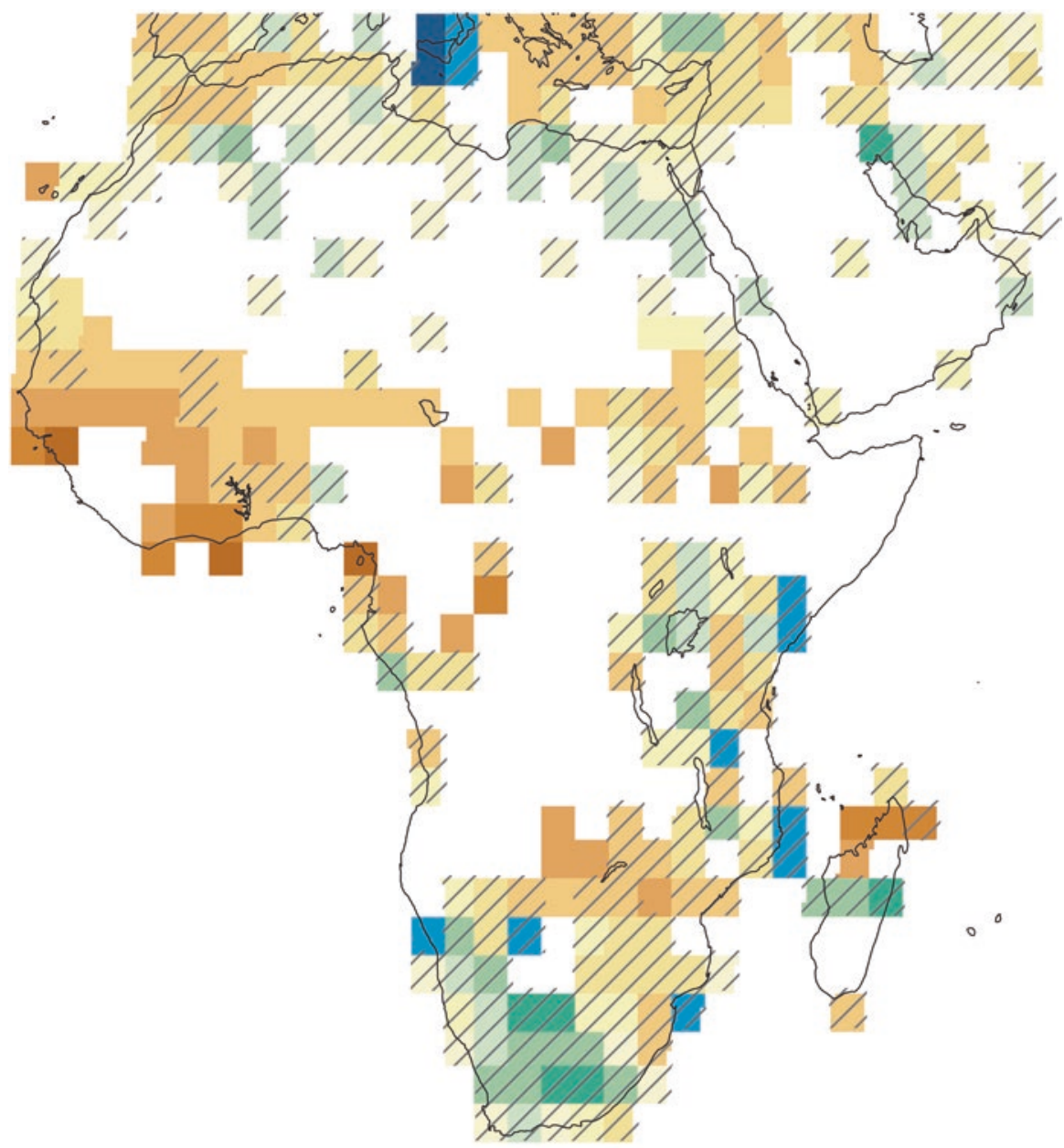

Trend in annual precipitation over 1951-2010 ( $\mathrm{mm} /$ year per decade)

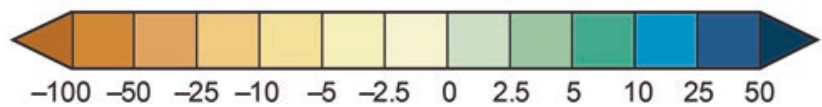

Fig. 2.1 Historical changes in precipitation from 1951 to 2010 (From Niang et al. 2014). The map has been derived from a linear trend. Areas with insufficient data are marked as white, solid colors indicate statistically significant trends at $10 \%$ level, and diagonal lines indicate areas where trends are not statistically significant 
Fig. 2.2 Historic time series for evaporative stress in Zambia during 2001-2017, showing a highly significant $(p<0.001)$ increase during this time period. (From https://climateserv. servirglobal.net, accessed 27 January 2018)

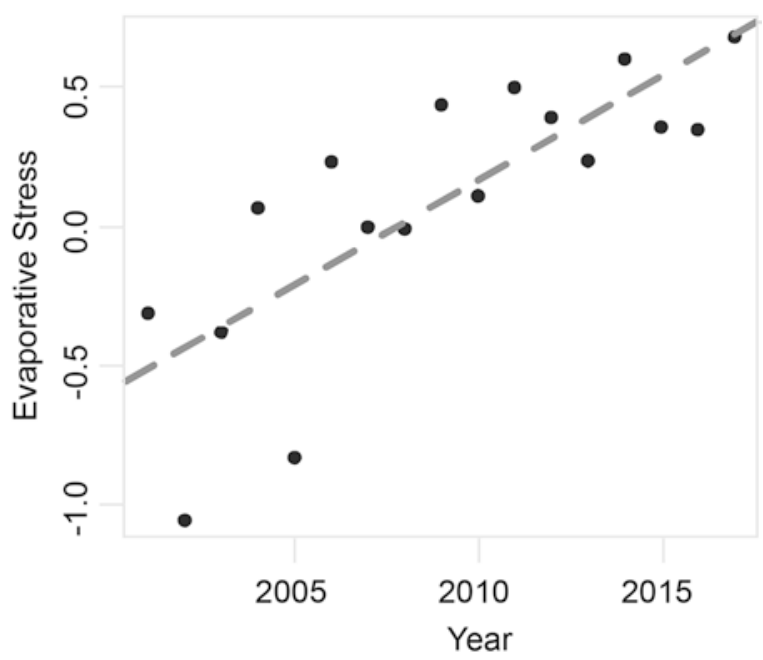

and Zimbabwe, show rapid and statistically significant decreases in precipitation. By contrast, South Africa and limited parts of East and North Africa have experienced increased rainfall. At the same time, increased temperatures are leading to higher rates of evapotranspiration, which produces drier soil conditions (Girvetz and Zganjar 2014). Evaporative stress consistently increased in Zambia between 2001 and 2017 (Fig. 2.2). Even in the face of increasing precipitation, it is possible for the aridity of soils to increase. In southern Africa from 1961 to 2000, an increasing frequency of dry spells was accompanied by an increase in the intensity of daily rainfall, which has implications for runoff (New et al. 2006).

\subsection{Future: Climate Model Projections for Africa}

General circulation models (GCMs) provide the most straightforward and scientifically accepted way to project future climate conditions. However, climate-change simulations performed with GCMs are only possible at coarse resolutions (typically 50-100 km grid cells) that are not detailed enough to assess regional and national impacts. Agricultural livelihoods, soils and local climatic conditions vary vastly at much smaller spatial scales. Spatial downscaling techniques can and should be used to bring these coarse scale maps down to a finer resolution.

Despite their limitations, GCMs are the most commonly used tool to analyze changes in climates at a variety of spatial scales. The latest GCMs available - the Coupled Model Intercomparison Project Phase 5 (CMIP5)—suggest that temperature increases for Africa with the current emissions trajectory (i.e. RCP 8.5) is $1.7{ }^{\circ} \mathrm{C}$ by the $2030 \mathrm{~s}, 2.7{ }^{\circ} \mathrm{C}$ by the 2050 s, and $4.5^{\circ} \mathrm{C}$ by the 2080 s (Fig. 2.3). Even under the lowest greenhouse gas emissions scenario, by 2030 the climate average is 

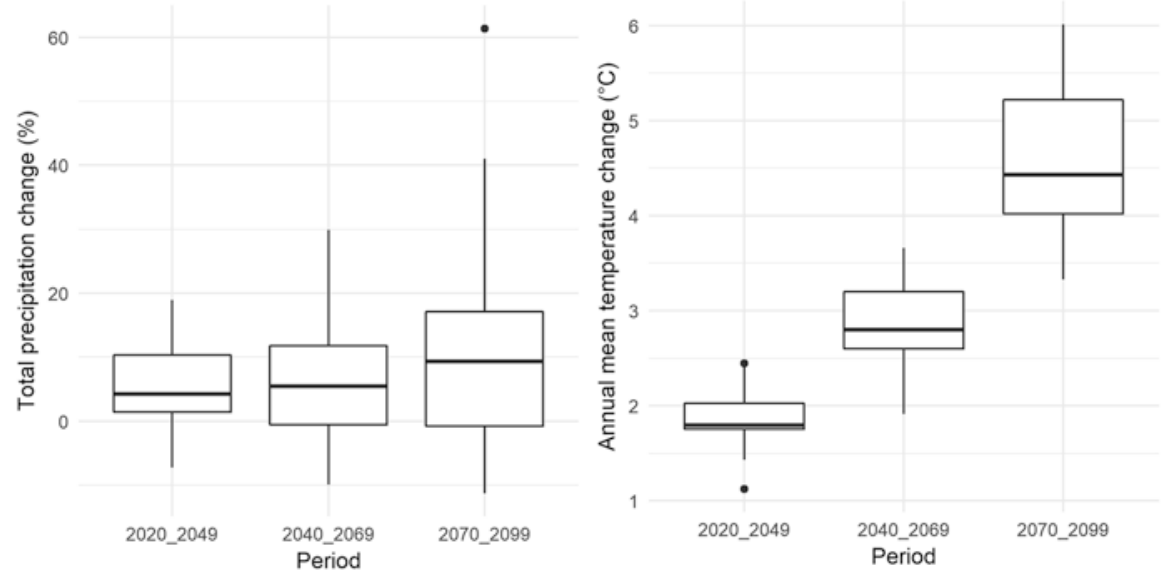

Fig. 2.3 Projected changes in annual mean temperature (in ${ }^{\circ} \mathrm{C}$ ) and total annual precipitation (in percentage) for the African continent as projected by 33 general circulation models (GCMs) of the CMIP5 model ensemble under RCP 8.5 and three different time periods. Thick black horizontal lines represent the median, boxes show the interquartile range, and whiskers represent the 5-95th percentiles of the data

projected to be completely different from what has ever been experienced historically (Girvetz et al. 2009, climatewizard.ciat.cgiar.org).

Future precipitation is much more difficult to model (Sillmann et al. 2013; Ramirez-Villegas et al. 2013). The median of the CMIP5 models indicates that by 2050, under the higher emission scenario (RCP 8.5, Fig. 2.4), annual precipitation will increase across much of eastern and central Africa, while decreasing across parts of southern, western and northern Africa (Fig. 2.4). Increases of over $200 \mathrm{~mm}$ and more than $25 \%$ annually are shown in some places, as well as decreases of over $100 \mathrm{~mm}$ and more than $20 \%$ in other places. Not all climate models agree on the magnitude or even direction of change. However, there are some places with high agreement among the climate models: over $80 \%$ of the climate models agree on decreased precipitation in the future for some parts of northern and southern Africa (Niang et al. 2014).

Precipitation is also projected to change differently in different months, with alterations to the onset, length and cessation of the growing season. For example, in Tanzania precipitation is projected to increase during the middle of the wet season (November-May) and to decrease at the wet season's beginning (SeptemberOctober) and end (May-June) (see http://climatewizard.ciat.cgiar.org/SBSTA/ Africa_2050/). Overall precipitation is projected to increase, but within a shorter time frame, indicating both shortening of the rainy season and an increased frequency of extreme precipitation events.

Even in areas experiencing increased precipitation, crop production systems can be affected by worsening water stress. Depending on the timing of rainfall, the amount of the temperature increase, and the changes in cloud cover (and hence in 

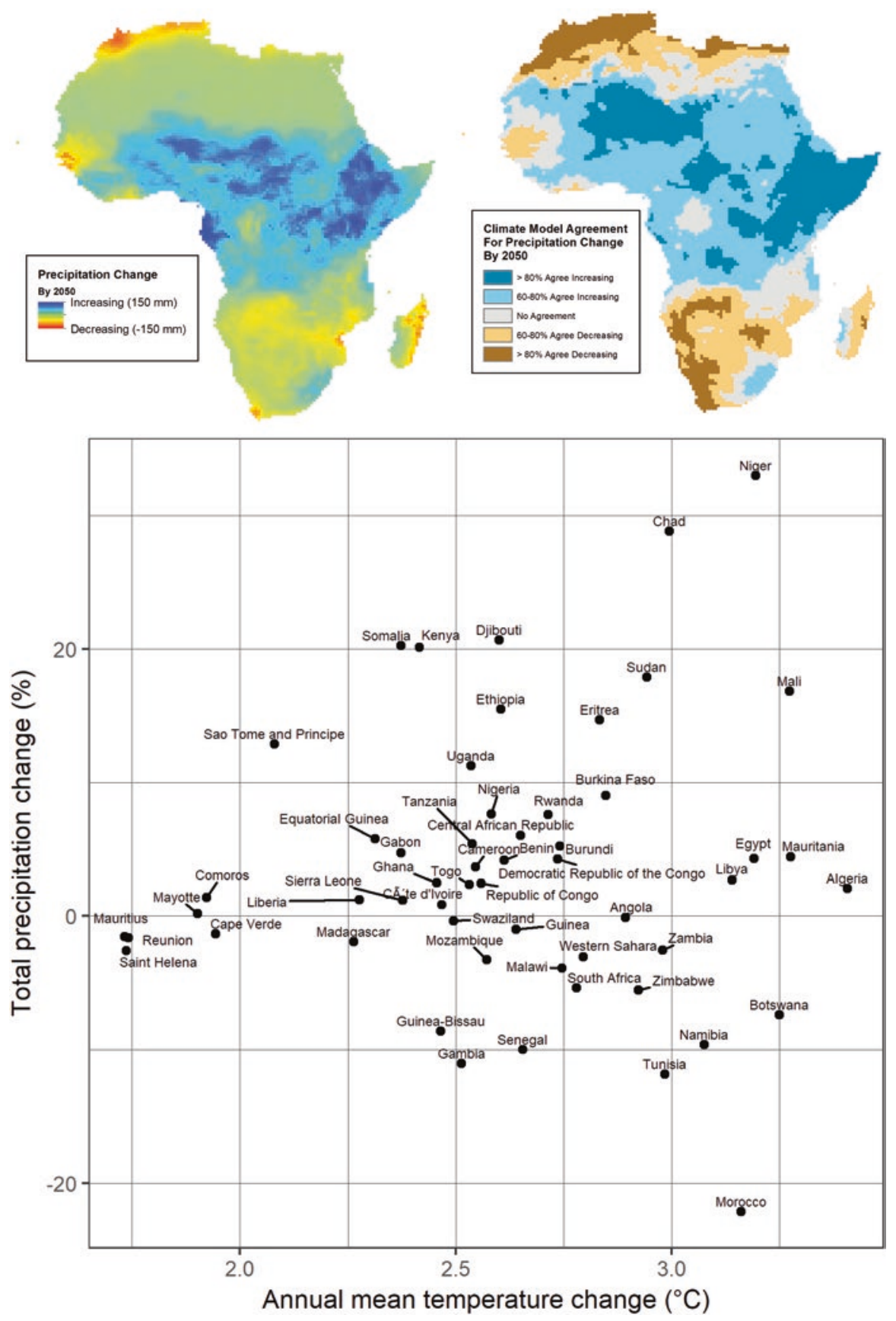

Fig. 2.4 Projected changes in total annual precipitation by 2050 (top left), climate model agreement (top right), and average change in precipitation and temperature, by country (bottom) 


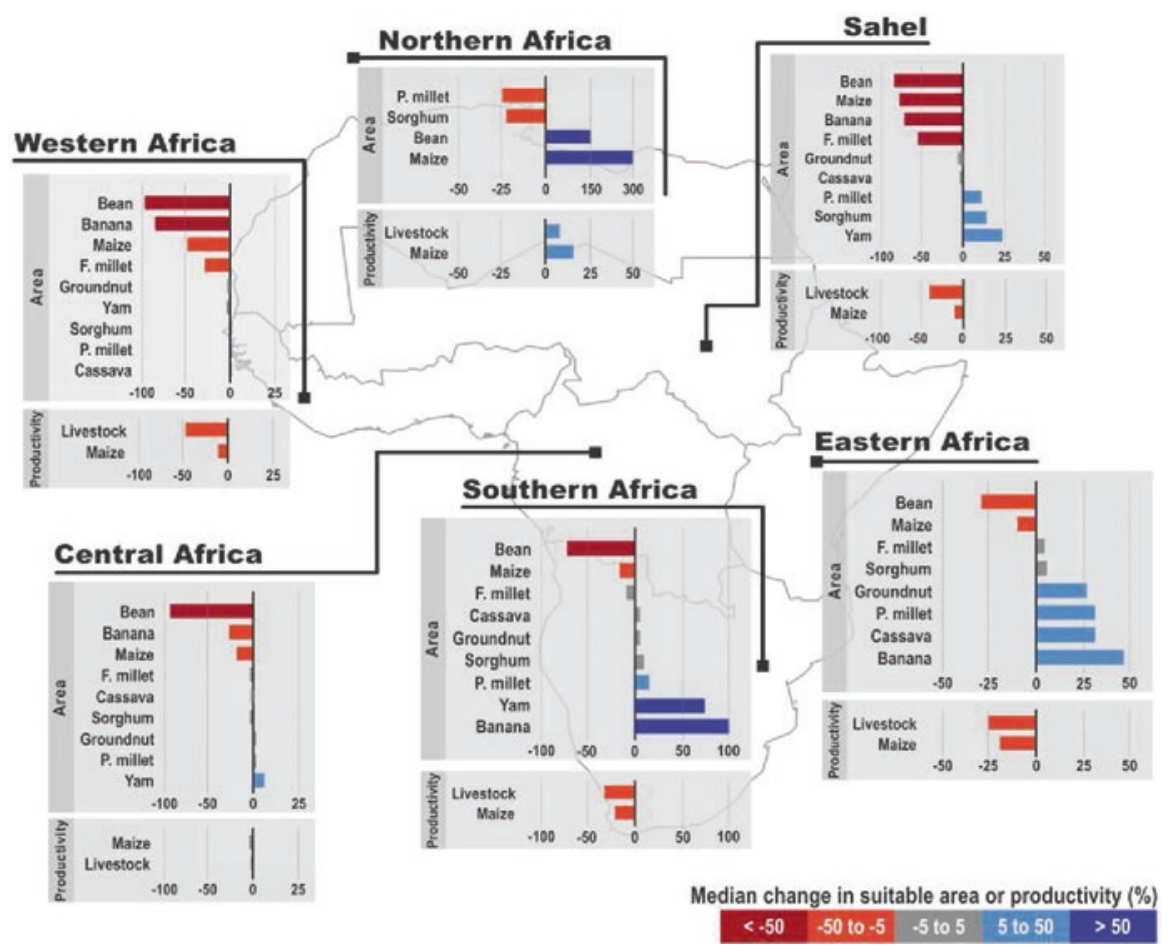

Fig. 2.5 Projected median changes in climatically suitable area and productivity by 2050 s and RCP8.5, relative to a historical period (1970-2000). Median values given are based on ensemble simulations of niche and productivity models, and therefore should be interpreted in light of associated uncertainties. Livestock productivity refers to annual net primary productivity (ANPP) of rangelands (a proxy for livestock productivity), rather than to a direct measure of meat or milk productivity. (Source: Dinesh et al. 2015)

incoming shortwave radiation), many places are likely to have less available water both in streams and in the soil, because warmer temperatures will cause more water to evaporate directly from the soil or to be transpired through plants (Girvetz and Zganjar 2014).

Changes to temperature and precipitation have immediate implications for food production and security across the continent (Niang et al. 2014; Porter et al. 2014; Muller et al. 2011; Rosenzweig et al. 2014). Current growing areas of maize and beans are projected to experience yield reductions of $12-40 \%$ by the 2050 s. The climate suitability of most major crops is also projected to shift as climate warms (Rippke et al. 2016; Zabel et al. 2014). Ramirez-Villegas and Thornton (2015) have shown that two of Africa's staple crops-maize and beans-are projected to have severe decreases in suitability across much of the continent (Fig. 2.5). Increasing atmospheric levels of carbon dioxide is likely to affect the nutrient content of plants, resulting in serious protein and micro-nutrient cold spots in parts of sub-Saharan Africa (Medek et al. 2017; Myers et al. 2014, 2015a, b). This poses a serious 
concern for food security and nutrition. While adaptation in the short- and mid-term may help some areas to continue growing these crops, by the end of the century it is estimated that over $30 \%$ of the area where maize is grown and over $60 \%$ of the area where beans are grown would need to grow entirely different crops (Rippke et al. 2016).

Some crops are much more resilient than maize and beans to changes in climate. In southern Africa, Ramirez-Villegas and Thornton (2015) showed that the suitable area for beans decreased greatly and maize decreased slightly, whereas other crops_-banana, yam and pearl millet-increased in range. Similar results were found in East Africa, where maize and beans are projected to experience major decreases in suitable area, whereas cassava, groundnut, pearl millet and banana are projected to increase. These more resilient crops could be promoted as replacement options for areas that require adaptation.

Under climate change, pressures from pests, weeds and diseases are also expected to increase. In the highland regions of East Africa, warming trends could lead to the expansion of crop pests - such as the coffee berry borer-into previously coldlimited areas (Jaramillo et al. 2011). Threats to banana production could come from range expansion of burrowing nematodes (Nicholls et al. 2008) and black leaf streak disease. Striga weed, a major cause of cereal yield reduction in sub-Saharan Africa, could become a more widespread problem because of changes in temperature, rainfall and seasonality (Niang et al. 2014). By contrast, climate change may reduce the range of major cassava pests including whitefly, cassava mealybug, cassava brown streak virus and cassava mosaic geminivirus (Jarvis et al. 2012). However, certain areas of current cassava production - including Southeast Africa and Madagascarmay see an increase in whiteflies, mites and mealybugs (Bellotti et al. 2012). In the case of livestock, changes in temperature and rainfall could increase the suitability of the main tick vector of East Coast fever across much of Southern Africa (Olwoch et al. 2008).

\subsection{Implications for Development}

\subsubsection{Adapting African Agriculture to Climate Change}

African agriculture must adapt in order to ensure food and nutritional security. Management adjustments and crop breeding will be critical in the short- and midterm, whereas at longer timescales planned transformations will likely be necessary (Rippke et al. 2016; Rickards and Howden 2012). Farmers and agricultural service providers-input suppliers, extension, financial services, safety net programs, etc.-will need to become resilient to new climate variability.

Although there is uncertainty in future climate projections, we have a great deal of solid information regarding how climate is already changing and the types of impacts farmers will need to address into the future. It is certain that temperatures 
are rising and will continue to rise at a rapid pace. Although climate models often do not agree on precipitation changes, there is considerable agreement on the trends in some locations. Moreover, precipitation is becoming more extreme in many places, often resulting in too much rain, too little rain, or rain that falls at the wrong time. A location might experience more overall rain during the growing season, but if it falls intensively in the beginning or middle of the season, the end of the season might be too dry, especially as hotter temperatures dry out soils. A single location might experience increased flooding during the middle of the rainy season and increased aridity later. This situation creates a need for crop varieties that can withstand waterlogging, help prevent erosion from heavy rains, and reach maturity during a shorter growing season.

Recent studies show that the types of management practices beneficial for adaptation and increased productivity are highly varied (Challinor et al. 2014; Lamanna et al. 2016). For instance, a recent review and meta-analysis of field studies in Uganda and Tanzania found more than 20 practices in each country that could improve adaptation and productivity, each with varying effectiveness depending on the farming system and site in question. The use of fertilizers (both organic and inorganic) and water saving techniques generally have the largest positive effects on crop productivity (Lamanna et al. 2015). Similar findings have been reported elsewhere in Africa (Rosenstock et al. this volume).

Improving the available crop varieties is a key mid-term strategy to increase productivity, improve production stability and adapt to projected climate changes. For example, although climate change will hurt bean production across Africa (Rippke et al. 2016; Ramirez-Villegas and Thornton 2015), heat-tolerant bean varieties could greatly reduce the impact (CIAT 2015). Current work on inter-specific crosses between common and tepary bean show promise for creating breeding lines that maintain yield under heat stress (CIAT 2015). Similarly, drought-tolerant varieties of maize could be an option for adaptation to reduced or inconsistent rainfall (Cairns et al. 2013; Rippke et al. 2016).

In the long-term, planned transformations will be required for some areas. Rippke et al. (2016) report that some 3-5\% of the arable land of sub-Saharan Africa may require a transformation out of crop-based systems to either livestock-based systems or to an entirely new land use.

\subsubsection{Collecting and Using Climate Data}

Historical data and climate projections clearly establish the need to act quickly to help African farmers adapt to a changing climate. Too often, however, CSA interventions are being promoted without a proper understanding of the climate risks for the specific areas involved. In some cases, reliable information on tightly focused geographical areas simply has not been collected. And even when good information is available from climate models and impact studies, often this information is not 
presented in ways that are accessible and comprehensible for those doing the CSA planning and implementation.

Although historic climate trends can be identified across the African continent, there is a general lack of high-resolution data, including for key biomes and agricultural areas (white areas in Fig. 2.1 showing insufficient data). Some national meteorological agencies have made efforts to improve the information available by, for example, combining weather-station information with satellite imagery to create high-resolution gridded historical time-series climate datasets (Dinku et al. 2016). Overall, though, there remains a lack of precise information for decision-making. Weather-station record keeping has declined over the past decades due to lack of maintenance and a failure to install new stations. This trend must be reversed. Increasing the available data on observed weather across the continent is critical to understanding the changes that have occurred already, to predict future changes, and to plan appropriately to address them.

Even as new data are collected, development practitioners and decision-makers should make use of the information and tools now available to help them understand the climate context. CMIP5 projections are freely available through the Climate Wizard, a web application that allows anyone to easily query and map downscaled future climate change projections for specific places globally (ClimateWizard.org). Similarly, the Servir ClimateServ allows for easy online analysis and querying of historic observed precipitation, vegetation greenness and moisture stress, as well as seasonal forecasts looking forward in the short-term for most of the globe (climateserv.servirglobal.net/). More training is needed to help those implementing CSA learn how to access and use these tools. Such training should include profiling of CSA opportunities, prioritization of investment portfolios, design and implementation of CSA projects, and assessing the results of CSA projects (Girvetz et al. 2017).

In conclusion, we would like to emphasize these key points:

- The climate has already changed, with temperatures continuing to rise and precipitation patterns changing, and more disruption is certain in coming years and decades.

- The collection of weather observations at local weather stations must improve, and should be incorporated with satellite data.

- Climate data and tools are available and accessible to practitioners. More effort, however, should be put into disseminating this information and ensuring that development practitioners understand how it can be used for CSA planning and implementation.

- Given the uncertainties surrounding exactly how climate change will affect specific places, the best CSA options are those that build resilience and help farmers cope with a wide range of climate risks, especially heat, drought, erosion and flooding.

Farmers are already suffering from the effects of climate change. Average temperatures are rising, rainfall is becoming less predictable, and extreme weather events are growing more common. The situation poses a real and ever-increasing threat to rural livelihoods and food security. Government, civil society and the pri- 
vate sector must work together urgently to collect and analyze climate information, make it accessible to decision-makers on the ground, and to ensure that CSA planning and implementation are carried out based on the best information available.

\section{References}

Belloti A, Herrera Campo BV, Hyman G (2012) Cassava production and pest management: present and potential threats in a changing environment. Trop Plant Biol 5(1):39-72

Cairns JE, Crossa J, Zaidi PH et al (2013) Identification of drought, heat, and combined drought and heat tolerant donors in maize. Crop Sci 53:1335-1346. https://doi.org/10.2135/ cropsci2012.09.0545

Challinor A, Wheeler T, Garforth C et al (2007) Assessing the vulnerability of food crop systems in Africa to climate change. Clim Chang 83:381-399. https://doi.org/10.1007/s10584-007-9249-0

Challinor AJ, Watson J, Lobell DB et al (2014) A meta-analysis of crop yield under climate change and adaptation. Nat Clim Chang 4:287-291. https://doi.org/10.1038/nclimate2153

CIAT (2015) Developing beans that can beat the heat. International Center for Tropical Agriculture (CIAT), Cali

Collins M, Knutti R, Arblaster J et al (2013) Long-term climate change: projections, commitments and irreversibility. In: Stocker TF, Qin D, Plattner GK et al (eds) Climate change 2013: the physical science basis, Contribution of Working Group I to the Fifth Assessment Report of the Intergovernmental Panel on Climate Change. Cambridge University Press, Cambridge, UK

Dinesh D, Bett B, Boone R et al (2015) Impact of climate change on African agriculture: focus on pests and diseases. CGIAR Research Program on Climate Change, Agriculture and Food Security (CCAFS), Copenhagen

Dinku T, Cousin R, Corral J et al (2016) The ENACTS approach: transforming climate services in Africa one country at a time. World Policy Papers, pp 1-24

Girvetz EH, Zganjar C (2014) Dissecting indices of aridity for assessing the impacts of global climate change. Clim Chang 126:469-483

Girvetz EH, Zganjar C, Shafer S et al (2009) Applied climate-change analysis: the Climate Wizard tool. PLoS One 4(12):e8320

Girvetz EH, Corner-Dolloff C, Lamanna C et al (2017) CSA-plan: strategies to put CSA into practice. Agric Dev 30:12-16

Hartmann DL, Klein Tank AMG, Rusticucci M et al (2013) Observations: atmosphere and surface. In: Stocker TF, Qin D, Plattner G-K et al (eds) Climate change 2013: the physical science basis, Contribution of Working Group I to the Fifth Assessment Report of the Intergovernmental Panel on Climate Change. Cambridge University Press, Cambridge, UK

IPCC (2012) IPCC 2012: summary for policymakers. In: Field CB, Barros V, Stocker TF et al (eds) Managing the risks of extreme events and disasters to advance climate change adaptation, A Special Report of Working Groups I and II of the Intergovernmental Panel on Climate Change. Cambridge University Press, Cambridge, UK

Jaramillo J, Muchugu E, Vega FE et al (2011) Some like it hot: the influence and implications of climate change on coffee berry borer (Hypothenemus hampei) and coffee production in East Africa. PLoS One 6(9):e24528

Jarvis A, Ramirez-Villegas J, Herrera Campo BV et al (2012) Is cassava the answer to African climate change adaptation? Trop Plant Biol 5(1):9-29

Kirtman B, Power SB, Adedoyin JA et al (2013) Near-term climate change: projections and predictability. In: Stocker TF, Qin D, Plattner G-K et al (eds) Climate change 2013: the physical science basis, Contribution of Working Group I to the Fifth Assessment Report of the Intergovernmental Panel on Climate Change. Cambridge University Press, Cambridge, UK 
Lamanna C, Namoi N, Kimaro A et al (2016) Evidence-based opportunities for out-scaling climate-smart agriculture in East Africa. CCAFS Working Paper no. 172. Copenhagen

Medek DE, Schwartz J, Myers SS (2017) Estimated effects of future atmospheric CO2 concentrations on protein intake and the risk of protein deficiency by country and region. Environ Health Perspect 125(8):087002

Müller C, Cramer W, Hare WL et al (2011) Climate change risks for African agriculture. Proc Natl Acad Sci. https://doi.org/10.1073/pnas.1015078108

Myers SS, Wessells KR, Kloog I et al (2015a) Effect of increased concentrations of atmospheric carbon dioxide on the global threat of zinc deficiency: a modelling study. Lancet Glob Health 3(10):e639-e645

Myers S, Zanobetti Z, Kloog I et al (2015b) Increasing CO2 threatens human nutrition. Nature 510:139-142

New M, Porter JR, Xie L et al (2006) Evidence of trends in daily climate extremes over southern and west Africa. J Geophys Res 111:D14102. https://doi.org/10.1029/2005JD006289

Niang I, Ruppel OC, Abdrabo MA et al (2014) Africa. In: Barros VR et al (eds) Food security and food production systems. Climate Change 2014: impacts, adaptation, and vulnerability. Part B: regional aspects. Contribution of adaptation and vulnerability, Working Group II Contribution to the IPCC 5th Assessment Report of the Intergovernmental Panel on Climate Change. Cambridge University Press, Cambridge, UK, pp 1199-1265

Nicholls T, Norgrove L, Masters G (2008) Innovative solutions to new invaders: managing agricultural pests, diseases and weeds under climate change. In: Proceedings of agriculture in a changing climate: the new international research frontier, vol 3. ATSE Crawford Fund fourteenth annual development conference, pp 9-14

NOAA (2018) Climate at a glance: global time series. NOAA National Centers for Environmental information. Available at: http://www.ncdc.noaa.gov/cag/

Olwoch J, Reyers B, Engelbrecht F et al (2012) Climate change and the tick-borne disease, Theileriosis (East Coast fever) in sub-Saharan Africa. J Arid Environ 72(2):108-120

Ramirez-Villegas J, Thornton PK (2015) Climate change impacts on African crop production, CCAFS Working Paper no. 119. CGIAR Research Program on Climate Change, Agriculture and Food Security (CCAFS), Copenhagen Available at: www.ccafs.cgiar.org

Ramirez-Villegas J, Challinor AJ, Thornton PK et al (2013) Implications of regional improvement in global climate models for agricultural impact research. Environ Res Lett 8:24018

Rickards L, Howden SM (2012) Transformational adaptation: agriculture and climate change. Crop Pasture Sci 63:240-250. https://doi.org/10.1071/CP11172

Rippke U, Ramirez-Villegas J, Jarvis A et al (2016) Timescales of transformational climate change adaptation in sub-Saharan African agriculture. Nat Clim Chang 6(6):605-609

Seneviratne SI, Nicholls N, Easterling D et al (2012) Changes in climate extremes and their impacts on the natural physical environment. In: Field CB, Barros V, Stocker TF et al (eds) Managing the risks of extreme events and disasters to advance climate change adaptation. A special report of working groups I and II of the intergovernmental panel on climate change. pp 109-230

Shackleton S, Ziervogel G, Sallu SM et al (2015) Why is socially-just climate change adaptation in sub-Saharan Africa so challenging? A review of barriers identified from empirical cases. Wiley Interdiscip Rev Clim Chang 6(3):321-344 
Sillmann J, Kharin VV, Zhang X et al (2013) Climate extremes indices in the CMIP5 multimodel ensemble: part 1. Model evaluation in the present climate. J Geophys Res Atmos 118:17161733. https://doi.org/10.1002/jgrd.50203

Zabel F, Putzenlechner B, Mauser W (2014) Global agricultural land resources—a high resolution suitability evaluation and its perspectives until 2100 under climate change conditions. PLoS One 9:e107522. https://doi.org/10.1371/journal.pone.0107522

Open Access This chapter is licensed under the terms of the Creative Commons Attribution 4.0 International License (http://creativecommons.org/licenses/by/4.0/), which permits use, sharing, adaptation, distribution and reproduction in any medium or format, as long as you give appropriate credit to the original author(s) and the source, provide a link to the Creative Commons license and indicate if changes were made.

The images or other third party material in this chapter are included in the chapter's Creative Commons license, unless indicated otherwise in a credit line to the material. If material is not included in the chapter's Creative Commons license and your intended use is not permitted by statutory regulation or exceeds the permitted use, you will need to obtain permission directly from the copyright holder.

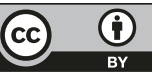

